\title{
Cytotoxicity of hydroxydihydrobovolide and its pharmacokinetic studies in Portulaca oleracea L. extract
}

\author{
Liang Xu, Xiaojun Tao, Yucong Gao, Wenjie Zhang, Yihan Meng, Cuiyu Li, Mingyue Jiang, \\ Xixiang Ying*
}

School of Pharmacy, Liaoning University of Traditional Chinese Medicine, Dalian, China

\begin{abstract}
Hydroxydihydrobovolide (HDB) was for the first time isolated from Portulaca oleracea $\mathrm{L}$. and then its cytotoxicity against SH-SYTY cells was studied. Moreover, a rapid and sensitive ultra-high performance liquid chromatographic (UHPLC) method with bergapten as internal standard (IS) was developed and validated to investigate the pharmacokinetics of $\mathrm{HDB}$ in rats after intravenous and oral administrations of extract (POE). The UHPLC analysis was performed on a Diamonsil C18 analytical column, using acetonitrile-water $(35: 65, v / v)$ as the mobile phase with $U V$ detection at $220 \mathrm{~nm}$. The calibration curve was linear over the range of $0.2-25 \mu \mathrm{g} / \mathrm{mL}$ in rat plasma. The average extraction recovery was from 90.1 to $98.9 \%$, and the relative standard deviations (RSDs) of the intra- and inter-day precisions were less than 4.7 and $4.1 \%$, respectively. The results showed that $50 \mu \mathrm{M}$ HDB had significant cytotoxicity on the SH-SY5Y cells, which was rapidly distributed with a Tmax of 11 min after oral administration and presented a low absolute bioavailability, $4.12 \%$.
\end{abstract}

Uniterms: Portulaca oleracea L./hydroxydihydrobovolide. Portulaca oleracea L./ hydroxydihydrobovolide/cytotoxicity. Portulaca oleracea L./hydroxydihydrobovolide/pharmacokinetics. Hydroxydihydrobovolide/Ultra-high performance liquid chromatography.

\section{INTRODUCTION}

Portulaca oleracea L., a member of family Portulacaceae, with diffusely branched and succulent stems, is distributed extensively in temperate and tropical regions (Zhu et al., 2009). P. oleracea L., being a popular traditional Chinese medicine recorded in the Chinese Pharmacopoeia is commonly used for removing heat, counteracting toxicity, cooling blood, hemostasia and antidysentery (The Pharmacopoeia PRC, 2015). Pharmacological studies demonstrated that the plant possessed many activities including the neuroprotective effect (Ahmed, Moneim, 2013), anti-tumor (Zhao et al., 2013), anti-inflammatory (Meng et al., 2016), woundhealing effect (Rashed et al., 2003), antibacterial (Chan et al., 2015) and hypocholesterolemic (Movahedian, Ghannadi, Vashirnia, 2007). With its popularity, more and more scholars thus pay more attention to its bioactive components, such as terpenes (Xin et al., 2008), phenolic

*Correspondence: X. Ying. School of Pharmacy. Liaoning University of Traditional Chinese Medicine, 77 Shengming 1 Road, DD Port, 116600 - Dalian, China. E-mail: yingxixiang@163.com acids and coumarins (Awad, 1994), flavonoids (Xu, Yu, Chen, 2006) and alkaloids (Tian et al., 2014). Also, the pharmacokinetics of some of the bioactive components of P. oleracea L. (Cheng et al., 2012; Zhang et al., 2015) was reported recently.

In the present study, hydroxydihydrobovolide (HDB), which belongs to the $\alpha-\beta$-unsaturated $\gamma$-lactone and presenting potent anti-HIV activity (Zhang et al., 2005), was for the first time, isolated from Portulaca oleracea L. with its pharmacokinetics investigated in rat plasma following intravenous and oral administration using a rapid and specific UHPLC method, and its absolute bioavailability was discussed. In addition, the cytotoxicity of HDB on the SH-SY5Y cells was studied.

\section{MATERIAL AND METHODS}

\section{Plant materials and chemicals}

The whole herbs of $P$. oleracea L. were collected in Shijiazhuang (Hebei, China) in June 2014, and identified by Prof. Tingguo Kang. Voucher specimens (No. 20140312) were deposited at School of Pharmacy, 
Liaoning University of Traditional Chinese Medicine. The internal standard (IS), bergapten was provided by Sichuan Weikeqi Biological Technology Co., Ltd (Chengdu, China) (Figure 1b). Methanol and acetonitrile were all of HPLC grade provided by Damao Chemical Reagent Plant (Tianjin, China). All other reagents were of analytical grade purchased from Jinfeng Chemical Factory (Tianjin, China), and the water was purified with Milli-Q ${ }^{\circledR}$ Biocel Ultrapure Water System (Millipore, Bedford, MA, USA).
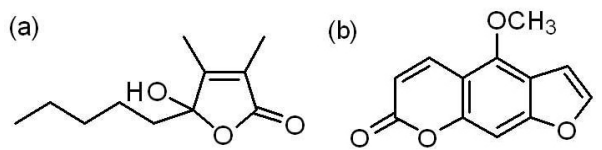

FIGURE 1 - Structures of hydroxydihydrobovolide (a) and IS (b).

\section{Isolation and identification}

A sample $(80 \mathrm{~kg})$ of the whole herb of P. oleracea L. was extracted with water twice and each for 2 hours. The crude extract was then concentrated and passed through a porous-polymer resin (AB-8, Tianjin, China), eluted with water, $50 \%$ and $70 \%$ ethanol, successively. The fraction of $70 \%$ extraction was evaporated under reduced pressure to obtain the $P$. oleracea $\mathrm{L}$. extract (POE) of $200 \mathrm{~g}$, and $150 \mathrm{~g}$ of the extract was partitioned with ethyl acetate, and subsequently evaporated and adsorbed on a polyamide resin (80-100 mesh, Taizhou LuqiaoSijia Biochemical Plastic Factory, Zhejiang, China) column. After eluting with water, as well as 30\%, $50 \%$ and $70 \%$ ethanol stepwise, the fraction eluted with $70 \%$ ethanol was evaporated and subjected to silicagel column chromatography with ethyl acetate and methanol as the gradient eluent $(10: 1,5: 1,1: 1)$ to obtain 1-100 fractions, and then the fractions of 70-100 were repeatedly subjected to ODS column chromatography under medium pressure and eluted with methanol/water $(70: 30, \mathrm{v} / \mathrm{v})$ to obtain 10 fractions. The fractions of 6 and 7 were purified with Sephadex LH-20 and eluted with methanol-water (70:30) to get the pale yellow oil compound $(16 \mathrm{mg})$ with the purity checked by UHPLC more than $98 \%$. Its molecular formula $\left(\mathrm{C}_{11} \mathrm{H}_{18} \mathrm{O}_{3}\right)$ with 3 degrees of unsaturation was deduced from a protonated molecular ion peak at $\mathrm{m} / \mathrm{z} 199.1108[\mathrm{M}+\mathrm{H}]^{+}$of HR-ESITOF-MS. ${ }^{1} \mathrm{H}-\mathrm{NMR}\left(500 \mathrm{MHz}, \mathrm{CDCl}_{3}\right) \delta: 1.96(1 \mathrm{H}, \mathrm{br}$, H-6a), $1.93(3 \mathrm{H}, \mathrm{d}, \mathrm{J}=0.75 \mathrm{~Hz}, \mathrm{H}-11), 1.81(3 \mathrm{H}, \mathrm{d}, \mathrm{J}=$ $0.85 \mathrm{~Hz}, \mathrm{H}-12), 1.77$ (1H, br, H-6b), 1.29 (4H, m, H-8, -9), $1.27(2 \mathrm{H}, \mathrm{m}, \mathrm{H}-7), 1.17$ (1H, br, OH), $0.88(3 \mathrm{H}, \mathrm{t}, \mathrm{J}$ $=6.3 \mathrm{~Hz}, \mathrm{H}-10) ;{ }^{13} \mathrm{C}-\mathrm{NMR}\left(100 \mathrm{MHz}, \mathrm{CDCl}_{3}\right) \delta: 172.18$ (C-2), 157.80 (C-4), 125.28 (C-3), 107.02 (C-5), 35.99
(C-6), 31.55 (C-7), 22.59 (C-8), 22.42 (C-9), 13.91 (C10), 10.69 (C-11), 8.42 (C-12). The ${ }^{1} \mathrm{H}$ NMR, ${ }^{13} \mathrm{C}$ NMR and DEPT spectrum showed 11 carbon resonances, including three methyls (C-10, -11, -12), four methylenes (C-6, -7, -8, -9) and one carbonyl (C-2), two olefinic (C$3,-4)$ carbons, and one quaternary carbon. The HMBC spectrum showed correlations of $\mathrm{H}-11 / \mathrm{C}-3, \mathrm{C}-4, \mathrm{C}-5$, $\mathrm{C}-12, \mathrm{H}-12 / \mathrm{C}-2, \mathrm{C}-3, \mathrm{C}-4$ and $\mathrm{C}-11, \mathrm{H}-10 / \mathrm{C}-8$, C-9; H-8, H-9, H-10/C-7, H-8, H-9/C-10, H-8/C-9 or H-9/C-8 along with the ${ }^{1} \mathrm{H}-{ }^{1} \mathrm{H}$ COSY cross-peaks of $\mathrm{H}-8$ and $\mathrm{H}-9$ with $\mathrm{H}-10$; $\mathrm{H}-7$ with $\mathrm{H}-10$; $\mathrm{H}-11$ with $\mathrm{H}-12$, indicating that there is a structure of oxole with methyl substitute located at C-3, C-4 and a carbon chain fragment attached to the oxole. To satisfy the molecular formula, the presence of one hydroxyl, together with the carbon chain substituted at C-5, was reasonably arranged considering the downfield chemical shift of C-5 ( $\delta \mathrm{C} \mathrm{107.02).} \mathrm{The}$ relative configuration of HDB was established by NOE spectrum, which showed the following correlations: H-6a with H-6b, H-8, H-9 with H-10, H-11 and H-12, $\mathrm{H}-11$ with $\mathrm{H}-12$; $\mathrm{H}-7$ with $\mathrm{H}-10$ and the active hydrogen in hydroxy, as shown in Figure 2. Following the above evidence, the structure of the compound was confirmed as shown in Figure 1a, and ${ }^{1} \mathrm{H} \mathrm{NMR}\left(500 \mathrm{MHz}, \mathrm{CDCl}_{3}\right)$ and ${ }^{13} \mathrm{C}$ NMR $\left(500 \mathrm{MHz}, \mathrm{CDCl}_{3}\right.$ ) spectral data were listed in Table I. The spectral data were consistent with previous report of hydroxydihydrobovolide (Zhang et al., 2014b).

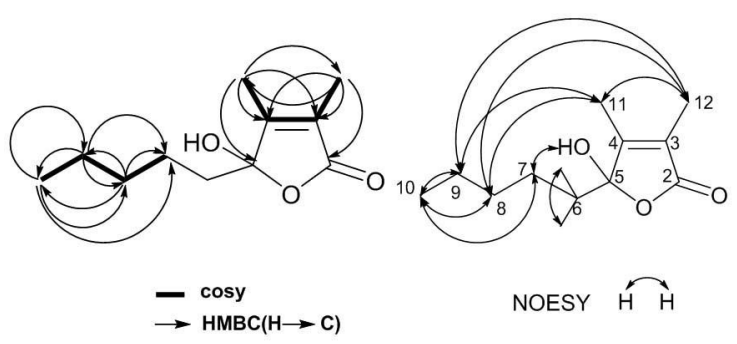

FIGURE 2 - ${ }^{1} \mathrm{H}-{ }^{1} \mathrm{H}$ COSY, key HMBC and NOESY correlations of hydroxydihydrobovolide.

\section{Cell culture}

SH-SY5Y cells, which were kindly provided by Prof. Jingxian Yang (Liaoning University of Traditional Chinese Medicine, China), are human neuroblastomaderived cell line and have neuron-like characteristic. The cells were cultured in DMEM high glucose medium (Hyclone, USA) supplemented with 10\% fetal bovine serum (Zhejiang Tianhang Biotechnology Co., Ltd.) and $100 \mathrm{U} / \mathrm{mL}$ penicillin-streptomycin (Hyclone, USA) at $37^{\circ} \mathrm{C}$ with $5 \% \mathrm{CO}_{2}$. 
TABLE I - ${ }^{1} \mathrm{H}-\mathrm{NMR}$ and ${ }^{13} \mathrm{C}-\mathrm{NMR}$ spectral data of hydroxydihydrobovolide $\left(500 \mathrm{MHz}, \mathrm{CDCl}_{3}\right)$

\begin{tabular}{cccc}
\hline Position & $\boldsymbol{\delta}_{\mathbf{C}}$ & Type & $\boldsymbol{\delta}_{\mathbf{H}}(\boldsymbol{J}$ in Hz $)$ \\
\hline 2 & 172.18 & $\mathrm{C}=\mathrm{O}$ & \\
3 & 125.28 & $\mathrm{C}$ & \\
4 & 157.80 & $\mathrm{C}$ & \\
5 & 107.02 & $\mathrm{C}$ & \\
6 & 35.99 & $\mathrm{CH}_{2}$ & $1.96(1 \mathrm{H}, \mathrm{br}, \mathrm{H}-6 \mathrm{a})$ \\
& & & $1.77(1 \mathrm{H}, \mathrm{br}, \mathrm{H}-6 \mathrm{~b})$ \\
7 & 31.55 & $\mathrm{CH}_{2}$ & $1.27(2 \mathrm{H}, \mathrm{m})$ \\
8 & 22.59 & $\mathrm{CH}_{2}$ & $1.29(2 \mathrm{H}, \mathrm{m})$ \\
9 & 22.42 & $\mathrm{CH}_{2}$ & $1.29(2 \mathrm{H}, \mathrm{m})$ \\
10 & 13.91 & $\mathrm{CH}_{3}$ & $0.88(3 \mathrm{H}, \mathrm{t}, J=6.3 \mathrm{~Hz})$ \\
11 & 10.69 & $\mathrm{CH}_{3}$ & $1.93(3 \mathrm{H}, \mathrm{d}, J=0.75 \mathrm{~Hz})$ \\
12 & 8.42 & $\mathrm{CH}_{3}$ & $1.81(3 \mathrm{H}, \mathrm{d}, J=0.85 \mathrm{~Hz})$ \\
5 & & $\mathrm{OH}$ & $1.17(1 \mathrm{H}, \mathrm{br})$ \\
\hline
\end{tabular}

\section{Cell viability assay}

Cell viability was assayed by CCK-8 (Cell Counting Kit-8, Beyotime Co., Ltd., China) according to the manufacturer's instructions (Li, Zhang, Chen, 2008). In brief, $1.6 \times 10^{4}$ cells/well of SH-SY5Y were seeded in 96well plates and cultured in $100 \mu \mathrm{L}$ DMEM medium. After $24 \mathrm{~h}$, the cells were treated with fresh medium containing different concentrations of $\operatorname{HDB}(0.01,0.1,1,10,50 \mu \mathrm{M})$ for $48 \mathrm{~h}$, then the cells were washed with PBS three times and incubated in $100 \mu \mathrm{L}$ DMEM medium with $10 \% \mathrm{CCK}$ 8 solution. After incubation at $37^{\circ} \mathrm{C}$ for $2 \mathrm{~h}$, absorbance at $450 \mathrm{~nm}$ was measured with a microplate reader (Mindray, China). The cell viability of \% control in different concentration of HDB was plotted as means \pm standard deviations (SD) of cell proliferation rate. The data was analyzed with One-way ANOVA (SPSS software version 11.5, SPSS, Chicago, USA), and statistical significance was considered at $p<0.05$ or $p<0.01$.

\section{Chromatographic system and conditions}

A Shimadzu UHPLC system (Japan) was equipped with a Solvent Delivery Pump (Shimadzu LC-30AD), a vacuum degasser (DGU-20A) a Shimadzu UV-VIS spectrophotometric detector (SPD-20A) and ChemStation software (Shimadzu). Chromatographic separation of HDB from the IS was achieved on an analytical column (Diamonsil C18, $4.6 \mathrm{~mm} \times 150 \mathrm{~mm}$, i.d., $5 \mu \mathrm{m}$ ) (Dikma Technologies, Bejing, China) connected with a guard column $($ KRC18, $35 \times 8.0 \mathrm{~mm}$, i.d., $5 \mu \mathrm{m})$, (Dalian
Create Science and Technology Co., Ltd, Dalian, China). The mobile phase for UHPLC analysis consisting of acetonitrile-water $(35: 65, v / v)$ was passed under vacuum through a $0.22 \mu \mathrm{m}$ filter membrane and degassed before use. The analysis was carried out at a flow rate of $1 \mathrm{~mL} / \mathrm{min}$ with the detection wavelength set at $220 \mathrm{~nm}$ and column temperature at $40^{\circ} \mathrm{C}$.

\section{Preparation of calibration standards and quality control samples}

The stock solutions of HDB and IS were prepared in methanol to yield the concentrations of $133 \mu \mathrm{g} / \mathrm{mL}$ and $18.2 \mu \mathrm{g} / \mathrm{mL}$, respectively. The working solutions were prepared by diluting stock solution in series to concentrations over the range of $0.4-50 \mu \mathrm{g} / \mathrm{mL}$. All the solutions were stored at $4{ }^{\circ} \mathrm{C}$ before use. Seven calibrators $(0.2,0.5,1.0,2.0,4.0,10.0$, and $25.0 \mu \mathrm{g} / \mathrm{mL})$ of HDB and IS were prepared by adding the series of standard working solutions of HDB $(50 \mu \mathrm{L})$ and the IS $(0.91 \mu \mathrm{g} / \mathrm{mL}, 20 \mu \mathrm{L})$ to $100 \mu \mathrm{L}$ of drug-free rat plasma. Quality control (QC) samples were prepared at three concentrations (low, mid, and high) covering the whole range of the calibration curve. Low concentration $(0.5 \mu \mathrm{g} / \mathrm{mL})$ was 2.5 times of the lower limit of quantification, the high concentration (20 $\mu \mathrm{g} / \mathrm{mL}$ ) was $80 \%$ of the upper limit of quantification and the mid one $(4.0 \mu \mathrm{g} / \mathrm{mL})$ was near the geometric mean of them. The whole QC samples were stored at $-20{ }^{\circ} \mathrm{C}$ until analysis.

\section{Animals and blood sampling}

Male Wistar rats $(250 \pm 20 \mathrm{~g})$ were supplied by the Laboratory Animal Service Center of Liaoning Changsheng Biotechnology Co. Ltd. (Benxi, China). They were housed in an environmentally controlled breeding room for 1 week before the experiments and were fed regular chow with standard laboratory food and water ad libitum and fasted 12-16 h prior to the experiment. All animal studies were carried out according to the requirement of the National Act on the Use of Experimental Animal (China) that was approved by the Committee of Ethics of Animal Experimentation of Liaoning University of Traditional Chinese Medicine. For the pharmacokinetics, the two groups of rat (five rats per group) were assigned to receive POE solution via intravenous at a single dose of $0.75 \mathrm{~mL} / \mathrm{kg}$ (equivalent to $5.9 \mathrm{mg} / \mathrm{kg}$ of $\mathrm{HDB}$ ), and oral administration at a dosage of $10 \mathrm{~mL} / \mathrm{kg}$ (equivalent to $78.9 \mathrm{mg} / \mathrm{kg}$ of HDB), respectively. Serial blood samples $(0.3 \mathrm{~mL})$ were obtained via the orbitalis vena at times of $3,5,8,11,15,20,25$, 
$30,45,60,90 \mathrm{~min}$ after administration and collected into heparinized centrifuge tubes. The blood samples were immediately centrifuged at $3,500 \mathrm{~g}$ for $15 \mathrm{~min}$ at room temperature. The plasma sample was stored at $-20{ }^{\circ} \mathrm{C}$ until analysis.

\section{Plasma sample preparation}

To $100 \mu \mathrm{L}$ plasma, $20 \mu \mathrm{L}$ of IS $(0.91 \mu \mathrm{g} / \mathrm{mL})$ and $0.5 \mathrm{~mL}$ methanol were successively pipetted, followed by vortex mixing for $1 \mathrm{~min}$ and centrifuging at $3,500 \mathrm{~g}$ for $15 \mathrm{~min}$ to precipitate the protein. The supernatant was collected and evaporated to dryness at $40^{\circ} \mathrm{C}$ under a gentle stream of nitrogen. The dried residue was then reconstituted with $100 \mu \mathrm{L}$ mobile phase, and centrifuged at $15,000 \mathrm{~g}$ for $5 \mathrm{~min}$, and an aliquot $(20 \mu \mathrm{L})$ of the supernatant was injected into the UHPLC system for analysis.

\section{Method validation}

\section{Selectivity}

The selectivity was determined by comparing chromatograms of blank plasma obtained from rats prior to dosing with those of corresponding standard plasma spiked with HDB and bergapten, and samples from rats after administration of POE.

\section{Linearity, $L O D$ and $L O Q$}

The evaluation of the linearity was performed with a seven-point calibration curve over the concentration range of $0.2-25 \mu \mathrm{g} / \mathrm{mL}$. The peak area ratios of the analyte with IS were plotted against standard concentrations to establish calibration curves for HDB. The slope and intercept of the calibration graphs were calculated by weighted $\left(1 / \mathrm{c}^{2}\right)$ least squares linear regression. Limit of detection (LOD) and limit of quantification (LOQ) via diluting the QC samples stepwise were determined by $\mathrm{S} / \mathrm{N}=3$ and $\mathrm{S} / \mathrm{N}=10$ (signal-to-noise ratio), respectively, giving an acceptable accuracy (RE) within $20 \%$ and a precision (RSD) that did not exceed $20 \%$.

\section{Precision and accuracy}

The intra-day precision and accuracy were evaluated by determining the QC samples at three concentration levels with five replicates on the same day, while the inter-day values were assessed in the same way on three consecutive days. The precision was expressed as RSD, which should be less than $15 \%$, except at the LOQ where it should not exceed $20 \%$, and the accuracy of the assay was determined by comparing the means of the determined
HDB concentrations with the nominal concentrations. The mean percentage deviation from the nominal values expressed as RE which should be within $\pm 15 \%$ of the nominal value, except at LOQ where it should not exceed $\pm 20 \%$.

\section{Extraction recovery}

The extraction recoveries of HDB were determined by comparing the peak area of QC samples that were at low, mid, and high concentrations to that of the unextracted standard solutions containing the equivalent amount of analytes $(n=6)$.

\section{Stability}

Five aliquots of QC samples at low, mid, and high concentrations were prepared for stability assessment. Unextracted QC samples were subjected to the conditions as follows:short-term stability was determined by analyzing the QC plasma samples kept at ambient temperature $\left(25^{\circ} \mathrm{C}\right)$ for $4 \mathrm{~h}$; long-term stability was determined by analyzing the unextracted QC plasma samples stored at $-20^{\circ} \mathrm{C}$ for 1 month; freeze-thaw stability was investigated after three freeze $\left(-20^{\circ} \mathrm{C}\right.$ )-thaw (room temperature for 2-3 h) cycles; andpost-preparative stability was assessed by analyzing the extracted QC plasma samples kept in the autosampler at $4{ }^{\circ} \mathrm{C}$ for $12 \mathrm{~h}$. These samples were processed and analyzed and the concentrations obtained were compared with the nominal values of QC samples.

\section{Pharmacokinetics and statistical analysis}

Pharmacokinetic analysis of the data was performed using both compartmental and non-compartmental methods, with the assistance of DAS program (Chinese Pharmacology Society, Beijing, China). The compartmental parameters were generated, involving apparent volume of distribution at steady state $\left(\mathrm{V}_{\mathrm{dss}}\right), \alpha$ half-life $\left(\mathrm{t}_{1 / 2}\right), \beta$ half-life $\left(\mathrm{t}_{1 / 2 \beta}\right)$, and clearance rate $(\mathrm{CL})$. The area under the plasma concentration-time curve $\left(\mathrm{AUC}_{0 \rightarrow \mathrm{t}}\right)$ was calculated by the trapezoidal method. The area under the plasma concentration-time curve from zero to infinity $\left(\mathrm{AUC}_{0 \rightarrow \infty}\right)$ was calculated by means of the trapezoidal rule with extrapolation to infinity with terminal elimination rate constant. The peak plasma concentration $\left(\mathrm{C}_{\max }\right)$ and the peak time were directly obtained from the drug plasma concentration-time profiles. The terminal elimination rate $\left(\lambda_{z}\right)$ was estimated by the least-square regression analysis of at least last four time points of the semi-logarithmic plasma concentration-time curves, the terminal half-life $\left(\mathrm{t}_{1 / 2 \mathrm{z}}\right)$ was calculated according to the 
formula $t_{1 / 2 z}=0.693 / \lambda_{z}$. The mean residence time $(\mathrm{MRT})$ was determined by (AUMC)/AUC. AUMC is the area under the first momentof the plasma concentration-time curve. It is calculated as AUMC $=\int_{0}^{\infty} t \mathrm{Cd} t$. The Clearance (CL) following dosing was calculated as Dose/AUC $\mathrm{C}_{0-\infty}$. The absolute bioavailability (\%) was calculated using the following formula:

$$
\text { Bioavailability (\%) }=\frac{\mathrm{AUC}_{0-\infty \text { (p.o.) }} \times \operatorname{Dose}_{(\text {i.v. })}}{\mathrm{AUC}_{0-\infty \text { (i.v.) }} \times \operatorname{Dose}_{(\text {p.o. })}}
$$

\section{RESULTS AND DISCUSSION}

\section{Effect of HDB on the proliferation of SH-SY5Y cells}

To investigate the potential protective effect of HDB on nerve cells, SH-SY5Y cells were used to evaluate the effects on cell proliferation. As shown in Figure 3, after exposure to $\operatorname{HDB}(0.01,0.1,1,10$ and $50 \mu \mathrm{M})$ for $48 \mathrm{~h}$, the cell viability of 1 and $10 \mu \mathrm{M}$ of HDB slightly decreased, but there wasno statistical difference $(P>0.05)$. When the concentration of HDB was $50 \mu \mathrm{M}$, the cell growth was significantly inhibited $(P<0.01)$; while at the concentration less than $0.1 \mu \mathrm{M}$, HDB did not showsignificant effect on SH-SY5Y cells $(P>0.05)$. SH-SY5Y cells have dopamine- $\beta$-hydroxylase activity, acetylcholinergic, glutamatergic and adenosinergic characteristics, so they are often used as in vitro models of neuronal function and differentiation (Cho, Song, 2014; Ma et al., 2015). Meanwhile, SH-SY5Y cells also maintain their cancerous nature (Zhang et al., 2014a), and are often used as a human neuroblastoma cell line for anti-tumor research. In this study, HDB did not show significant neuroprotective or promoting proliferation effects when lower than $50 \mu \mathrm{M}$,

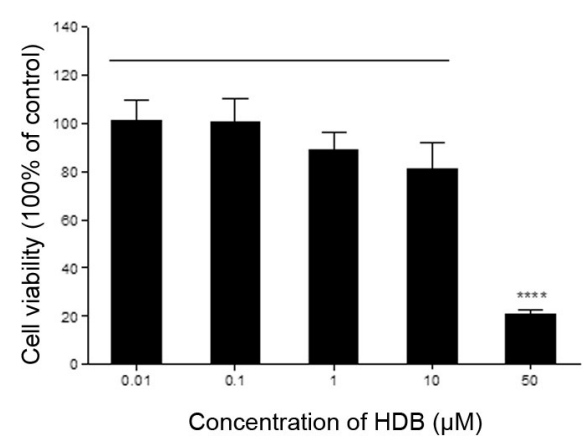

FIGURE 3 - Cytotoxicity of HDB on SH-SY5Y cells. After treated with $0.01,0.1,1,10$ and $50 \mu \mathrm{M}$ of HDB for $48 \mathrm{~h}$, cell growth was assayed by CCK- $8 \mathrm{Kit}$ at $450 \mathrm{~nm}$. Values indicate the mean $\pm \mathrm{SD}(n=6) .{ }^{* * * *} P<0.01$ compared to $0.01-10 \mu \mathrm{M}$ of HDB. but it may have growth-inhibiting orcytotoxic effects in SH-SY5Ycells when higher than $50 \mu \mathrm{M}$. Therefore, HDB may have anti-tumor activityat concentrations higher than $50 \mu \mathrm{M}$, its anti-tumor activity and mechanism needfurther study with more modelsin vitro or in vivo.

\section{Method development and optimization}

In consideration of the poor water-solubility of HDB, $10 \%$ ethanol was added to prepare the POE solution within safety limit for rats. To obtain perfect peak shape, suitable retention times and good separation among HDB, IS and endogenous substances, the mobile phase was chosen after several trials in various proportions with methanol-water (40:60-45:55, v/v), acetonitrile-water (30:70-40:60, v/v). There wereendogenous substances interfering with the determination of analytes when using methanol-water systems, and therefore acetonitrilewater was finally adopted. In addition, to deproteinize completely and extract analyte and IS simultaneously, acetonitrile and methanol have been tried, respectively; methanol was finally chosen because of its low boiling point and easy evaporation to dryness and high extraction recoveries of analyte and IS. The maximum absorptions of HDB at $220 \mathrm{~nm}$ were set to be the detection wavelength without endogenous interference and it was also found to be suitable for the analysis of IS.

\section{Method validation}

To determine the selectivity of this method, blank rat plasma, plasma spiked with HDB and IS, plasma samples from rats after intravenous and oral doses of POE were analyzed (Figure 4). The chromatograms indicated that there existed no interfering peaks in the region of the peaks of the analyte and IS. The retention times of HDB and IS were approximately $13.9 \mathrm{~min}$ and $11.1 \mathrm{~min}$, respectively. A complete baseline resolution of HDB and IS with adjacent peaks was obtained from the chromatogram. The total run time was $20.0 \mathrm{~min}$. The regression equation of the calibration curves was typically: $\mathrm{y}=1.0852 \mathrm{x}+0.0320$ $\left(\mathrm{SD}_{\text {slope }}=0.044, \mathrm{SD}_{\text {intercept }}=0.004\right)$ and the linear ranges for plasma were within $0.2-25 \mu \mathrm{g} / \mathrm{mL}$ with $\mathrm{r}=0.9926$. The LOD $(\mathrm{S} / \mathrm{N}=3)$ and the LOQ $(\mathrm{S} / \mathrm{N}>10)$ were 0.045 and $0.2 \mu \mathrm{g} / \mathrm{mL}$ in plasma, respectively. The RSD of three concentrations $(0.5,4.0,20.0 \mu \mathrm{g} / \mathrm{mL})$ ranged from 0.9 to $4.7 \%$ for intra-day assay and from 1.6 to $4.1 \%$ for interday assay, respectively. The REs of intra- and inter-day accuracy were within -1.4 to $6.6 \%$, and the data, which conform to the criteria for the analysis of biological sample according to guidance of US Food and Drug 
Administration (FDA, 2001) were listed in Table II. Mean extraction recoveries at three concentration levels for HDB ranged from $90.1 \%$ to $98.9 \%$ suggesting negligible loss during extraction. The short-term, long-term and freezethaw stability of HDB in plasma were shown in Table III, indicating that no remarkable degradation occurred during chromatography, extraction and storage processes for plasma samples.

\section{Pharmacokinetic studies}

Pharmacokinetic data were processed byDAS program (Chinese Pharmacology Society, Beijing, China). According to the AkaikeInformation Criterion (AIC) and $\mathrm{R}^{2}$, a two-compartment open model (weight $=1$ ) gave the best fit with the intravenous administration and a one-compartment open model (weight $=1$ ) for oral administration. The plasma concentration-time profile was shown in Figure 5, and the mean pharmacokinetic parameters of HDB in rats were summarized in Table IV. After administration of HDB, HDB can be detected up to 1.5 hafter both routes. The maximum concentrations in
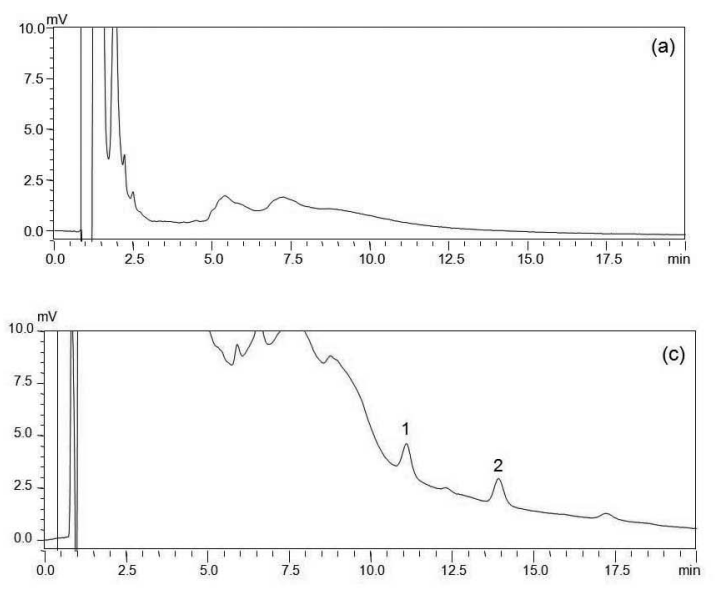

plasma after intravenous route $(1.300 \pm 0.429 \mu \mathrm{g} / \mathrm{mL})$ was about 2.2-fold higher than oral route $(0.587 \pm 0.13 \mu \mathrm{g} / \mathrm{mL})$, as well as the corresponding $\mathrm{AUC}_{0 \rightarrow \infty}$ was $37.22 \pm 15.7$ $\mu \mathrm{g} \cdot \mathrm{min} / \mathrm{mL}$ of intravenous route larger than $20.52 \pm 7.69$ $\mu \mathrm{g} \cdot \mathrm{min} / \mathrm{mL}$ of oral route, suggesting that the intravenous route had a higher absorption than oral route. $\mathrm{T}_{1 / 2 \alpha}$ to be $3.67 \pm 1.3 \mathrm{~min}, \mathrm{~T}_{1 / 2 \beta}$ to be $38.69 \pm 13.4 \mathrm{~min}$, the total body clearance to be $0.19 \pm 0.09 \mathrm{~L} / \mathrm{kg} \cdot \mathrm{min}$ and $\mathrm{MRT}_{0 \rightarrow \mathrm{t}}$ to be $25.22 \pm 2.99 \mathrm{~min}$ after intravenous administration meant that HDB presented in an extremely rapid distribution and elimination pattern, while HDB was rapidly absorbed into blood circulation with peak concentration occurring at $11 \mathrm{~min}$ after oral administration, and fastly eliminated from plasma with $\mathrm{t}_{1 / 2}(29.55 \pm 5.46 \mathrm{~min})$, $\mathrm{MRT}_{0 \rightarrow \mathrm{t}}(31.72 \pm 1.42 \mathrm{~min}), \mathrm{CL} / \mathrm{F}(4.40 \pm 2.0 \mathrm{~L} / \mathrm{kg} \cdot \mathrm{min})$, suggesting HDB administrated in two routes showed a little cumulative phenomenon in the body. In noncompartmental approach, the $\mathrm{CL} /$ Fof i.v. route $(0.190$ $\pm 0.093 \mathrm{~L} / \mathrm{kg} \cdot \mathrm{min})$ is smaller than that of oral route $(4.402 \pm 1.98 \mathrm{~L} / \mathrm{kg} \cdot \mathrm{min})$, indicating that HDB after intravenous administration eliminated slower in the blood than oral administration. The apparent volume of
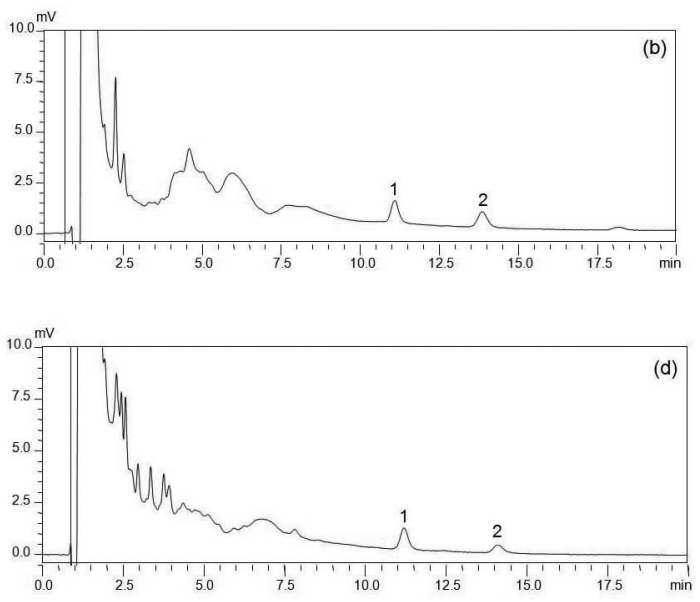

FIGURE 4 - Representative chromatograms of blank plasma (a), plasma spiked with hydroxydihydrobovolide and IS (b), plasma sample 8 min after the intravenous administration (c) and oral administration (d) of hydroxydihydrobovolide. Peak 1: IS; Peak 2: hydroxydihydrobovolide.

TABLE II - Precisions, accuracy and recovery of hydroxydihydrobovolide in rat plasma and recovery of hydroxydihydrobovolide in rat plasma

\begin{tabular}{cccccccc}
\hline $\begin{array}{c}\text { Nominal } \\
\text { Conc. } \\
(\boldsymbol{\mu g} / \mathbf{m L})\end{array}$ & $\begin{array}{c}\text { Mean } \pm \mathbf{S D} \\
(\boldsymbol{\mu g} / \mathbf{m L})\end{array}$ & $\begin{array}{c}\text { RSD } \\
\mathbf{( \% )}\end{array}$ & $\begin{array}{c}\text { RE } \\
\mathbf{( \% )}\end{array}$ & $\begin{array}{c}\text { Mean } \pm \mathbf{S D} \\
(\boldsymbol{\mu g} / \mathbf{m L})\end{array}$ & $\begin{array}{c}\text { RSD } \\
(\mathbf{\%})\end{array}$ & $\begin{array}{c}\text { RE } \\
(\mathbf{\%})\end{array}$ & $\begin{array}{c}\text { Recovery } \\
(\%)\end{array}$ \\
\hline 0.5 & $0.53 \pm 0.01$ & 1.6 & 6.5 & $0.53 \pm 0.01$ & 1.6 & 6.6 & $90.1 \pm 4.4$ \\
4.0 & $3.94 \pm 0.19$ & 4.7 & -1.4 & $3.98 \pm 0.16$ & 4.1 & -0.4 & $91.4 \pm 6.3$ \\
20.0 & $20.41 \pm 0.19$ & 0.9 & 2.0 & $20.43 \pm 0.36$ & 1.8 & 2.2 & $98.9 \pm 1.5$ \\
\hline
\end{tabular}

Intra-day: $n=5$; inter-day: $n=3$ days with 5 replicates per day; recovery, $n=6$ 
TABLE III - Stabilities of hydroxydihydrobovolide in rat plasma at three QC levels $(n=5)$

\begin{tabular}{cccc}
\hline \multirow{2}{*}{ Added conc. $(\boldsymbol{\mu g} / \mathbf{m L})$} & \multicolumn{3}{c}{ Accuracy $(\mathbf{\%}$, mean $\pm \mathbf{S D})$} \\
\cline { 2 - 4 } & Short-term stability & Long-term stability & Freeze-thaw stability \\
\hline 0.5 & $101.4 \pm 7.4$ & $99.1 \pm 2.0$ & $99.0 \pm 2.1$ \\
4 & $96.1 \pm 6.6$ & $96.6 \pm 7.7$ & $94.3 \pm 2.2$ \\
20 & $104.8 \pm 2.6$ & $97.8 \pm 2.1$ & $94.6 \pm 5.4$ \\
\hline
\end{tabular}
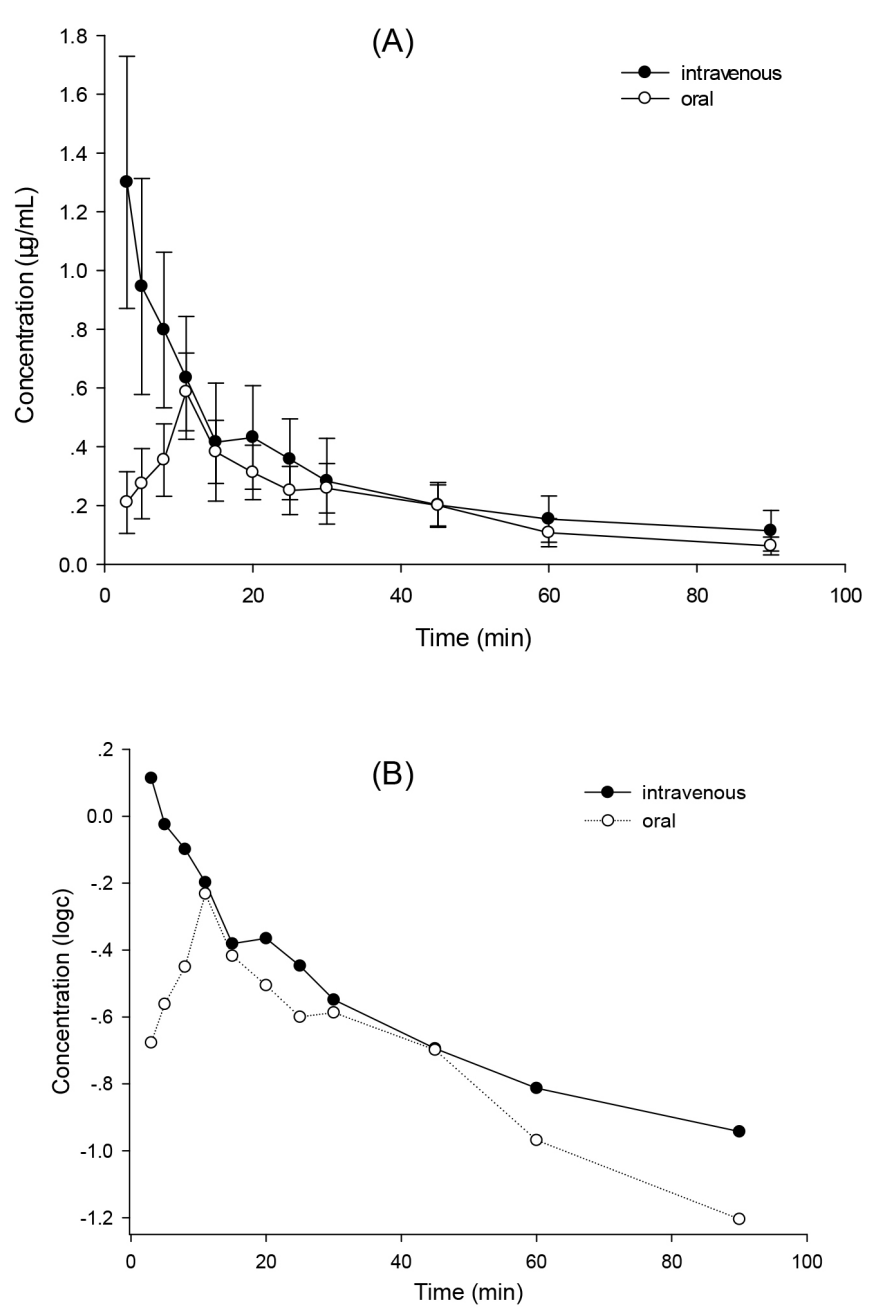

FIGURE 5 - Mean plasma concentration-time curves of hydroxydihydrobovolide in rats $(n=5)$ after the intravenous and oral administration at dose of $5.9 \mathrm{mg} / \mathrm{kg}$ and $78.9 \mathrm{mg} / \mathrm{kg}$, respectively. Figure A: c-t; Figure B: logc-t.

distribution $\left(\mathrm{V}_{\mathrm{dss}} / \mathrm{F}=170.25 \pm 46.3 \mathrm{~L} / \mathrm{kg}\right)$ was relatively large after oral administration, suggesting a main distribution of HDB in the tissues and organs rather than plasma. In contrast, $\mathrm{V}_{\mathrm{dss}} / \mathrm{F}=9.025 \pm 2.22 \mathrm{~L} / \mathrm{kg}$ after intravenous administration is very small, showing that HDB distributed mainly in plasma. The bioavailability of HDB can be calculated from the AUCs when administrated the extract in the intravenous and oral approaches. That is, HDB's absolute bioavailability after oral dosing of Portulaca oleracea L. Extract was $4.12 \%$ calculated via the formula of $\left(\mathrm{AUC}_{\text {p.o. }} / \mathrm{AUC}_{\mathrm{i} . \mathrm{v}}\right) \times\left(\right.$ Dose $_{\text {i.v. }} /$ Dose $\left._{\text {p.o. }}\right)$. Taking the absolute bioavailability into account, pharmacokinetic parameters $\left(\mathrm{CL}, \mathrm{Vd}_{\mathrm{ss}}\right.$ and terminal $\left.\mathrm{t}_{1 / 2}\right)$ after i.v. and oral dosing were similar (Table IV). The content of HDB in the extract was $18.67 \mathrm{mg} / \mathrm{g}$ determined by UHPLC method.

\section{CONCLUSION}

HDB, being the $\alpha-\beta$-unsaturated $\gamma$-lactone that possesses the potential bioactivities anti-bacteria (Ordonez et al., 2011) and anti-inflammatory (Rungeler et al., 1999) properties, was first found in P. oleracea L., and the effect on cell proliferation and its pharmacokinetics were investigated. The result showed that $50 \mu \mathrm{M}$ HDB had cytotoxicity on the SH-SY5Y cells, and HDB could be rapidly absorbed and distributed in rats after i.v. and oral administrations but with a low absolute bioavailability of $4.12 \%$ following the administration of POE.

\section{ACKNOWLEDGEMENT}

This study was supported by the Project of National Natural Science Foundation of China (Grant No. 81573546) and the Natural Science Foundation of Liaoning Province (No. 2015020699), China.

\section{REFERENCES}

AHMED, E.; MONEIM, A. The neuroprotective effects of purslane (Portulaca oleracea) on rotenone-induced biochemical changes and apoptosis in brain of rat. CNS Neurol Disord. Drug Targets. v.12, n.6, p.830-841, 2013.

AWAD, N. Lipid content and antimicrobial activity of phenolic constituents of cultivated Portulaca oleracea L. Bull. Fac. Pharm. Cairo Univ., v.32, n.1, p.137-142, 1994. 
CHAN, B.C.; HAN, X.Q.; LUI, S.L.; WONG, C.W.; WANG, T.B.; CHEUNG, D.W.; CHENG, S.W.; IP, M.; HAN, S.Q.; YANG, X.S.; JOLIVALT, C.; LAU, C.B.; LEUNG, P.C.; FUNG, K.P. Combating against methicillin-resistant Staphylococcus aureus-two fatty acids from Purslane (Portulaca oleracea L.) exhibit synergistic effects with erythromycin. J. Pharm. Pharmacol., v.67, n.1, p.107116,2015 .

CHENG, Z.Z.; XIE, M.; ZHANG, W.J.; CHENG, L.; DU, Y.; WANG, Y.J.; YING, X.X.; KANG, T.G. HPLC method for the simultaneous determination of four compounds in rat plasma after intravenous administration of Portulaca oleracea L. extract. Braz. J. Pharm. Sci., v.48, n.1, p.163$170,2012$.

CHO, H.J.; SONG, M.J. A Gammaherpesvirus establishes persistent infection in neuroblastoma cells. Mol Cells., v.37, n. 7, p.518-525, 2014.

FOOD AND DRUG ADMINISTRATION. FDA. Center for Drug Evaluation and Research (CDER). Guidance for Industry, Bioanalytical Method Validation. US Department of Health and Human Services. 2001. Available at: < https://www.fda.gov/downloads/drugs/ guidancecomplianceregulatoryinformation/guidances/ ucm070107.pdf>. Access on: March 02, 2016.

LI, X.T.; ZHANG, Y.; CHEN, G.Q. Nanofibrous polyhydroxyalkanoate matrices as cell growth supporting materials. Biomaterials, v.29, n.27, p.3720-3728, 2008.

MA, N.T.; ZHOU, R.; CHANG, R.Y.; HAO, Y.J.; MA, L.; JIN, S.J.; DU, J.; ZHENG, J.; ZHAO, C.J.; NIU, Y.; SUN, T.; LI, W.; KOIKE, K.; YU, J.Q.; LI, Y.X. Protective effects of aloperine on neonatal rat primary cultured hippocampal neurons injured by oxygen-glucose deprivation and reperfusion. J. Nat. Med., v.69, n.4, p.575-583, 2015.

MENG, Y.H.; YING, Z.M.; XIANG, Z.; HAO, D.; ZHANG, W.J.; ZHENG, Y.; GAO, Y.C.; YING, X.X. The antiinflammation and pharmacokinetics of a novel alkaloid from Portulaca oleracea L. J. Pharm. Pharmacol., v.68, n.3, p.397-405, 2016.

MOVAHEDIAN, A.; GHANNADI, A.; VASHIRNIA, M. Hypocholesterolemic Effects of Purslane Extract on Serum Lipids in Rabbits Fed with High Cholesterol Levels. Int. J. Pharmacol., v.3, n.3, p.285-289, 2007.
ORDONEZ, P.E.; QUAVE, C.L.; REYNOLDS, W.F.; VARUGHESE, K.I.; BERRY, B.; BREEN, P.J.; MALAGON, O.; SMELTZER, M.S.; COMPADRE, C.M. Sesquiterpene lactones from Gynoxys verrucosa and their anti-MRSA activity. J. Ethnopharmacol., v.137, n.2, p.1055-1059, 2011.

PHARMACOPOEIA OF THE PEOPLE'S REPUBLIC OF CHINA. Beijing: China Medical Science and Technology Press, 2015. Part 1. p.49-50.

RASHED, A.N.; AFIFI, F.U.; DISI, A.M. Simple evaluation of the wound healing activity of a crude extract of Portulaca oleracea L. (growing in Jordan) in Mus musculus JVI-1. J. Ethnopharmacol., v.88, n.2-3, p.131-136, 2003.

RUNGELER, P.; CASTRO, V.; MORA, G.; GOREN, N.; VICHNEWSKI, W.; PAHL, H.L.; MERFORT, I.; SCHMIDT, T.J. Inhibition of transcription factor NFkappaB by sesquiterpene lactones: a proposed molecular mechanism of action. Bioorg. Med. Chem., v.7, n.11, p.2343-2352, 1999.

TIAN, J.L.; LIANG, X.; GAO, P.Y.; LI, D.Q.; SUN, Q.; LI, L.Z.; SONG, S.J. Two new alkaloids from Portulaca oleracea and their cytotoxic activities. J. Asian Nat. Prod. Res., v.16, n.3, p.259-264, 2014.

XIN, H.L.; XU, Y.F.; HOU, Y.H.; ZHANG, Y.N.; YUE, X.Q.; LU, J.C.; LING, C.Q. Two novel triterpenoids from Portulaca oleracea L. Helv. Chim. Acta, v.91, n.11, p.20752080, 2008.

XU, X.Q.; YU, L.S.; CHEN, G.N. Determination of flavonoids in Portulaca oleracea L. by capillary electrophoresis with electrochemical detection. J. Pharm. Biomed. Anal., v.41, n.2, p.493-499, 2006.

ZHANG, H.J.; NGUYEN, V.H.; NGUYEN, M.C.; SOEJARTO, D.D.; PEZZUTO, J.M.; FONG, H.H.; TAN, G.T. Sesquiterpenes and butenolides, natural anti-HIV constituents from Litsea verticillata. Planta Med., v.71, n.5, p.452-457, 2005.

ZHANG, H.; PU, J.; QI, T.; QI, M.; YANG, C.; LI, S.; HUANG, K.; ZHENG, L.; TONG, Q. MicroRNA-145 inhibits the growth, invasion, metastasis and angiogenesis of neuroblastoma cells through targeting hypoxia-inducible factor 2 alpha. Oncogene, v.33, n.3, p.387-397, 2014a. 
ZHANG, J.; LIANG, Y.; LIAO, X.J.; DENG, Z.; XU, S.H. Isolation of a new butenolide from the South China Sea gorgonian coral Subergorgia suberosa. Nat. Prod. Res., v.28, n. 3 , p.150-155, 2014b.

ZHANG, W.J.; LI, D.; LENG, A.J.; AI, J.J.; DU, Y.; MENG, Y.H.; GAO, Y.C.; YING, X.X. Tissue distribution and excretion of the five components of Portulaca oleracea L. extract in rat assessed by UHPLC. Braz. J. Pharm. Sci., v.51, n.3, p.643-651, 2015.
ZHAO, R.; GAO, X.; CAI, Y.P.; SHAO, X.Y.; JIA, G.Y.; HUANG, Y.L.; QIN, X.G.; WANG, J.W.; ZHENG, X.L. Antitumor activity of Portulaca oleracea L. polysaccharides against cervical carcinoma in vitro and in vivo. Carbohydr. Polym., v.96, n.2, p.376-383, 2013.

ZHU, H.B; WANG, Y.Z.; LIU, Y.X.; XIA, Y.X.; TANG, T. Analysis of flavonoids in Portulaca oleracea L. by UV-Vis Spectrophotometry with comparative study on different extraction technologies. Food Anal. Meth., v.3, n.2, p.9097, 2009.
Received for publication on $15^{\text {th }}$ May 2016 Accepted for publication on $09^{\text {th }}$ March 2017 